\title{
LAWYERS' OBLIGATION TO PROVIDE LEGAL SERVICES
}

\author{
MR. JUSTICE J.C. MAJOR*
}

This article addresses ethical concerns in the legal profession and the challenge of not only providing legal services, but ensuring that the public has access to them. The author asserts that the whole profession is under an obligation to render legal services pro bono publico. Such has been the tradition since the beginning of the profession in thirteenth century Europe.

The article follows the history of pro bono work since medieval times, and compares the system in the United States with that in Canada. In the U.S. there is a greater commitment by firms to provide pro bono work, whereas in Canada, it lends to be on a more ad hoc basis. Canadian lavyers too often assume that government-funded legal aid systems adequately meet the public's needs. Legal aid, however, is facing increasing financial challenges. Moreover, a large number of Canadians who do not meet the eligibility requirements cannot afford to retain a lawyer. There is a need for a modified pro bono program that will assist not only the poor, but the working class as well.
Le présent article traite de questions éthiques dans la pratique du droit et du défi qui consiste non seulement à fournir des services juridiques mais aussi à en garantir l'accès au public. L'auteur affirme que la profession a l'obligation de rendre ses services bénévolement, ainsi que le veut la tradition depuis le début de la profession en Europe, au XIIT siècle.

$L$ 'article suit l'histoire du travail bénévole depuis l'époque médiévale et compare les systèmes américain et canadien. Aux États-Unis, les cabinets d'avocats tiennent plus fermement à ce principe, dont l'application est plus circonstancielle au Canada. Les avocats canadiens supposent trop souvent que l'aide juridique financée par le gouvernement répond adéquatement aux besoins du public. Cependant, cette aide doit surmonter des problèmes de financement croissants. De plus, un grand nombre de Canadiens qui n'y ont pas droit $n$ 'ont pas les moyens de retenir les services d'un avocat. Il est donc impératif d'offrir un programme d'aide juridique modifié à l'intention des pauvres, mais aussi de la classe laborieuse.

I am always happy to be back in Calgary and am especially happy to have this opportunity to address you at the opening of this conference on the important and timely issue of ethics in the legal profession. We have all heard more stories than we care to about lawyers being disciplined or violating their code of conduct, with the result that the public's confidence in the profession continues to be undermined. While the vast majority of the profession is unfailingly loyal to strict ethical guidelines, violations occur, and such violations seem to be occurring more frequently and are certainly being reported with greater frequency and relish. This conference will provide an occasion to consider the challenges facing the legal profession and the urgency to solve them.

I am particularly pleased to be able to speak to you in conjunction with the opening of the Professional Faculties building into which the Law Faculty has now moved. It is noteworthy that the law school is located in the Professional Faculties Building. It is a happy coincidence that the opening of the new building and this conference on ethics coincide, as it is the strict adherence to an ethical standard which is one of the historical hallmarks of a profession. This ethical standard is not only concerned with the immediate and narrow relationship between the lawyer and the client, but with the wide issue of the place of a profession in society and its corresponding obligation to 
that society as a whole. It is in this context that I would like to address the important subjects of:

(1) access to legal service, and

(2) lawyers' obligations to provide them.

I use the word important because unless lawyers act quickly to ensure that these requirements are met, their position as members of a self-regulated profession with a virtual monopoly is in serious danger of becoming something else.

The obligation on the part of lawyers to provide legal services is two-pronged. Both prongs are implicit in Rule XIV of the Canadian Bar Association's Code of Professional Conduct, which reads:

Lawyers should make legal services available to the public in an efficient and convenient manner that will command respect and confidence, and by means that are compatible with the integrity, independence and effectiveness of the profession.'

The commentary to this rule makes it clear that lawyers have the obligation to provide services to potential clients who want to retain them. A lawyer has the right to decline to act for a particular client but this right should not, subject to a conflict or other serious reason, be exercised if the probable result would be to deprive the person of representation. This is unlikely to arise in the city where lawyers are abundant, but it may arise in a rural area where lawyers may be scarce, or more insidiously, it may arise where the cause is neither popular nor profitable.

This is the first and general way in which lawyers come under an obligation to provide legal services. However, the more difficult problem is the second branch; that is, given the access, the obligation to provide the service. It is obviously no problem to provide services to clients who are able to pay. But the obligation extends beyond that. The obligation is that of the whole profession to render legal services pro bono publico - for the good of the general public.

I can almost sense a groan from the lawyers, that "Here comes another judge living without overhead to tell us that we charge too much." On the contrary, I sympathize with the difficult position of lawyers in these difficult economic times and hope to illustrate that your profession rises above commercialism.

It has long been part of the duty and tradition of the legal profession to provide services gratuitously for those who require them but cannot afford them. The profession, recognizing its commitment to the larger principle of justice, has traditionally not let such cases go unanswered merely because the individual is impecunious. Instead, the profession has collectively accepted the burden of such cases, thereby championing the cause of justice while at the same time sharing the cost that such cases entail. This is a tradition which dates to the very inception of the profession 
in medieval Europe in the thirteenth century. ${ }^{2}$ Until about 1250 A.D., the poor and disadvantaged relied on the church and canon lawyers to solve their legal problems. Such services were rendered by the church free of charge. By the middle of the 13th century, canonical legislators began to restrict the kinds of situations in which the legal claims of the poor and disadvantaged were justiciable in ecclesiastical courts. The poor had to look to the municipal courts and to civil lawyers for aid. As a result, towns and cities began to assume responsibility for providing legal assistance to indigent litigants, and legal aid to the poor became increasingly a civic as well as a religious obligation. ${ }^{3}$ At the same time, civil advocates, who were only beginning to emerge as an identifiable group, assumed the responsibility to aid the poor. This had previously been the sole responsibility of canon lawyers, most of whom were priests. James A. Brundage states in "Legal Aid for the Poor and the Professionalization of Law in the Middle Ages":

It is not coincidental, I would argue, that the period in which the lawyers began to bear a major share of the responsibility for furnishing legal aid to the poor and disadvantaged was also the period in which those same lawyers commenced to define themselves as members of a profession. Like physicians, who likewise began in this period to identify themselves as professionals, rather than simply as practitioners, medieval lawyers regarded it as one mark of their superiority to other craftsmen that they furmished their specialized skills to economically and socially disadvantaged persons without compensation. ${ }^{4}$

It is significant that at the same time that the poor became the responsibility of the civil advocates in terms of providing legal assistance, the advocates began organizing themselves into a self-governing profession.

The concept of service pro bono publico is found at the very core of the profession. In fact, it distinguishes the practice of law as a profession. This is more than a mere accident of history. Service of the public good is, by necessity, the premise upon which the profession is founded.

The oath that lawyers take when admitted to the bar compels them to work for greater justice. This does not mean that they work only for justice when they get paid, but perhaps more idealistically, that they work to create a more just society. A prerequisite to the attainment of justice is that all members of society have access to the machinery which dispenses it. Although equal access to the justice system is required by their legal oath, it is also fundamental to the efficient functioning of a democratic society. Without adequate access to a fair and equitable justice system for both rich and poor, we are simply paying lip service to the principle of equal justice. Rich and poor do, in theory, have equal rights. In reality, unless the poor have the means to enforce those rights, the principle of equality is illusory and means little. Moreover, so long as the poor are alienated and removed from one of the basic 
institutions in our society, they will neither consider themselves to be nor in fact be true participants in the democratic process.

Historically, there have been a number of ways in which lawyers have responded to the needs of the poor and disadvantaged to help ease the financial burden that access to the justice system entails. In 1495, during the reign of Henry VII, the British Parliament passed an Act entitled A Mean to Help and Speed Poor Persons in Their Suit. ${ }^{5}$ This Act established what was known as in forma pauperis proceedings, which permitted poor persons to appear in court without paying the usual court fees. This Act was still in existence at the time of Canadian confederation, and as a result, was inherited by all of our common law provinces as each entered confederation and assumed the laws of England. Some of the provinces have now codified "forma pauperis" in their Rules of Court. Rule 47 of the Supreme Court of Canada provides that an appellant whose net worth is less than $\$ 5,000$ may apply to have the registrar's fees and requirement for security waived. ${ }^{6}$ However, as this relates to court costs and not disbursements, it is of little practical use.

At the provincial level, the in forma pauperis procedure has generally fallen into disuse, but even in its modest form it should stand as a reminder of the early recognition of the obligation. In addition, there is the tradition of the inherent power of the court to appoint any member of the bar to represent an accused who appears for trial in need of counsel to be assured of a fair trial. While the existence of an organized government-funded legal aid system largely removes this need, nonetheless it serves as a reminder of the duty earlier mentioned. It was in its day the most common way an impecunious accused could obtain legal assistance. In fact, the English bar has a long history of gratuitous aid, helped by the fact that English barristers did not have offices as we know them. When they were not themselves engaged in representing a client in court, they would usually be present in the pit of the court and available to be appointed by the judge to commence acting immediately when the need arose. Such appointments usually earned no fees.

In the United States, there is jurisprudence in which lawyers appointed by the court to represent indigent accused without compensation have unsuccessfully challenged the constitutionality of the court's power to make such appointments. In one reported decision the court suspended a lawyer when he refused to comply with such an appointment. ${ }^{7}$

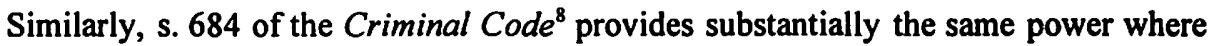
an accused is a party to an appeal and is unrepresented by counsel. This section gives the Court of Appeal the power to assign counsel to act on behalf of an impecunious accused where it appears desirable in the interests of justice. In most instances, the provincial attorney-general will pay a reasonable fee. 
These are examples of the ways in which the legal system has, since it began, recognized the needs of the poor. They are, however, merely examples of the larger obligation shared by the legal profession to ensure that the system is accessible not only to those who can afford the services, but also to those who cannot.

It is interesting to compare the pro bono traditions and practices in Canada and the United States. There is no doubt that the American bar appears more willing to recognize and respond to this litigation than the Canadian bar. It is not uncommon for large American law firms to assign specific lawyers to do only pro bono work, at a salary equal to those associates doing billable work. This is without prejudice to those lawyers in terms of advancement within the firm. The New York Times reported in late 1993 that the value of pro bono work performed in New York City alone in 1993 was estimated at 100 million dollars. 9

The April 1994 edition of the American Bar Association Journal reviewed the involvement of large American firms in pro bono efforts, and stated that many of these firms evaluate lawyers on their pro bono work as they do on their billable hours. ${ }^{10}$ Some large firms contribute more than 40,000 pro bono hours a year. As this is the equivalent of twenty lawyers working 2000 hours a year, obviously this would be restricted to firms in the 700 member range. All participating firms have pro bono coordinators to oversee the volunteer efforts being carried on by the firm, or have created separate pro bono departments. Last year, the American Bar Association issued a pro bono challenge to the 500 largest firms in the United States: firms accepting it agreed to contribute between 3 and 5 percent of their total billable hours to pro bono work. As of April, over 100 firms had joined.

While many Canadian firms provide ad hoc assistance, I am unaware of specific commitments to this effort. There are various factors that may explain this. The American profession is older, larger and better paid. Also important is the publicity given to this effort by the state bar associations and the American Bar Association to ensure that such acts are well known and do not go unnoticed by the public. I think this is proper: the public should know about the lawyers and law associations involved in pro bono work and credit, where due, should be generously given. Canadians have been reticent about both the existence of pro bono work and the acknowledgment of participating lawyers.

While Canadian lawyers generally recognize this duty, it may be that the existence of an organized and government-funded legal aid system in every province of the country has made them complacent and unaware of the importance of accepting their share of the burden to do pro bono work. We have undoubtedly developed the attitude that the problem has been taken care of by legal aid. Many of us assume that if someone is in need of legal advice and cannot afford it they still get it. This is a false assumption. 
The present legal aid system grew out of the profession's acknowledged obligation to help the poor, but was in no way intended to act as a replacement for its overriding obligations, nor as a full and complete response by the profession. Legal aid as it exists today was the direct result of lawyers' attempts to fulfil their obligation to serve the needy.

At the beginning of the twentieth century, legal aid, such as it was, was the result of private initiatives instituted to address localized problems. This was "true" pro bono work in the sense that lawyers volunteered their time to provide legal services, usually to a particular target group. These were often organized by church groups or social welfare organizations. There was no sense in which these efforts were co-ordinated or any thought that they should be.

The Canadian Bar Association ("C.B.A."), formed in 1915, revised its Canon of Legal Ethics in 1920 to indicate that a client's poverty may be reason to reduce one's fees, or even to charge nothing at all. Legal aid, at this stage, was considered as something to be left to the charity of individual lawyers. "By the 1930s, isolated legal aid facilities providing support in civil matters existed in all but the Atlantic provinces and the territories. These were all ad hoc measures and were not guided by the profession as such. Until this point, legal aid was entirely dependent upon enough lawyers assuming the burden and gratuitously providing the service.

The first involvement by the profession in the provision of legal aid came during the second world war, when the C.B.A. and the Department of National Defence established a nation-wide legal aid program for returning members of the armed forces and their dependants. All members of the Canadian bar were invited to participate. However, this program was only temporary, and the War Work Committee of the C.B.A. was disbanded in 1947. By this time, the benefits of a national legal aid plan had been realized, and the committee recommended that the C.B.A. establish legal aid services in larger cities. ${ }^{12}$ The C.B.A. shortly thereafter passed a resolution calling for the establishment of legal aid plans across Canada. The association recognized that no one should be denied access to legal service because of an inability to pay. The profession had the responsibility to provide legal services without charge to those who required it. This was not just perceived as a local responsibility, but was stated by the C.B.A. to be "the duty, individually, of all who are admitted to the Bar to assume and discharge a fair share of such responsibility." ${ }^{13}$

The first institutionalized system of compensatory legal aid with government support was established in Ontario in 1951. Until this time, it had been organized and offered free of charge by the profession. ${ }^{14}$ Over the next several years, other provinces followed Ontario's example and established government-funded legal aid programs. In

1 D. Hoehne, Legal Aid in Canada (Lewiston, N.Y.: The Edwin Mellen Press, 1989) at 40.

$12 \quad$ Ibid. at 56.

13 M.P. Reilly, "The Origins and Development of Legal Aid in Ontario" (1988) 8 Windsor Yearb. Access Justice 81 at 97-98.

$14 \quad$ Hoehne, supra note 11 at 58. 
1972, the Federal Department of Justice began cost-sharing for legal aid costs in criminal cases. ${ }^{15}$

As is clear from this brief history of the development of legal aid in this country, the impetus for the system we have came from the profession's recognition that it had an obligation to provide legal services to the poor. Unfortunately, it now appears that the existence of legal aid has blurred recognition by the profession that this obligation still exists. It is time to be reminded that the obligation does indeed exist. The present legal aid system in this country is facing a financial crisis. Even for those people who meet the eligibility requirements, there are a number of services, particularly in the civil law, which are not covered. There are people for whom the pro bono work of lawyers is the only way to achieve redress. The increasing expense of the legal system has resulted in it being inaccessible to large groups whose means make them ineligible for legal aid, but who yet cannot afford to retain a lawyer. In an ironic way, poor people in this respect may actually be better off than those with higher incomes, as they are eligible for legal aid. For most of the more modest wage earners, or the "working poor," the legal system is perceived as, and is in fact, expensive and inaccessible.

The cost of legal services involve more than lawyers' fees. There are experts, transcripts, loss of income, and lawyers' overhead. Whatever the breakdown of the expense, law suits such as custody disputes, unlawful dismissals or, to add to one's aggravation, being mistakenly charged with a serious criminal offence, can cost from $\$ 3,000$ to $\$ 100,000$ and more. Obviously in many cases accounts of that size cannot be fully paid. Nonetheless, it is an enforceable debt. It should not be assumed that these fees are either improper or arbitrary. While it is true that legal fees can be taxed or reviewed by the court, I am speaking of fees that have passed that scrutiny. They are fees that follow the rules, but are beyond the ability of all but a few to pay. These are costs that can bankrupt a middle-class family. Such examples are the exception, but not so exceptional as to be unheard of. Most often the costs of legal services to most people are, like other professional fees, painful but manageable.

Legal fees are frequently generated by our adversarial system of law. As a result of this system, 50 percent of litigants are going to lose, and the legal fees are more salt in their wounds. Legal fees are like life insurance: they don't usually provide anything tangible. I mention this to illustrate that legal fees are something that are unwelcome and imposed by circumstances, not by choice. The inevitable resentment of such fees increases the need to find methods of making the services accessible and affordable.

Legal aid is being squeezed by government cutbacks. There is a growing gap between those who need legal aid and those who can qualify. This is unsatisfactory and the continuing efforts of the bar to close that gap must be maintained.

There exists in most lawyers' practices a form of ad hoc pro bono that is integral to being a lawyer. It is not organized and it is not always an "and/or" proposition that you 
either work for nothing or you get paid: in certain circumstances there are reduced fees, contingency fees or no fees. While it is sometimes effective, it is generally different from lawyer to lawyer and the public is unaware of its existence, or how to access it.

At a more innocent time in our history, all professionals set their fees based on the ability to pay. Under that system the rich, theoretically at least, subsidized the poor for professional help. Today that tradition has disappeared primarily at the insistence of the client. More and more fees are simply a consequence of billable time; there is little assessment of factors such as results, responsibility or effort. The time spent on the file is now the determinant of what the bill should be, and consequently accounts for services are less professional, in that there is little room to assess what is a reasonable fee under the circumstances of the particular case.

While lawyers need to be fairly compensated, at the same time they share an obligation to help those for whom the legal system is inaccessible. Lawyers must consider once again what it means to call themselves professionals. This will force a return to the recognition that a portion of their time is owed to making the system accessible to all, and that the public must be aware of that duty.

Undoubtedly, the economic difficulties of the sustained recession and the increase in the number of lawyers act as disincentives to any pro bono initiative. Contrary to generally accepted wisdom, lawyers as a class are not wealthy. In today's competitive environment there are arguably more lawyers than clients. Practicing law imposes heavy obligations for relatively modest returns. There are exceptions, and while the profession has many privileges, money is not one. The public would be surprised at the average income received directly from practice. Practitioners are humanly concerned with financial survival. Nonetheless, it is precisely in difficult times that the obligation is most acute.

We need a formal and focused pro bono program. This I call modified pro bono work because it is different from traditional pro bono work. That is, it would apply not just to the poor, but to those earlier referred to as the "working poor" - people who have some means but not enough to pay standard legal fees. In those cases the lawyer would be compensated, but at a lesser rate. There would in effect be contributions from both the lawyer and the client. If this proposal is to work it would require provincial law societies to be involved in providing enforceable guidelines. While I hope it is unnecessary, it may require various law societies to implement mandatory pro bono and modified pro bono work. With some imagination, alternative methods of delivering this kind of legal service can be developed.

Even now, law firms should have a means by which pro bono work by lawyers in the firm is accounted for and made public. As I mentioned earlier, the absence of wide publicity for pro bono work and the lawyer performing it is one of the differences between Canada and the United States, and is a serious impediment to attracting lawyers to active pro bono work. Lawyers who provide pro bono services should be publicly and frequently recognized. 
Clearly, penalizing a member of a firm financially for pro bono work should not happen. The profession has to renew its professionalism, and do so in such a way that the public is aware of the various avenues of accessing legal services.

Pro bono work, traditional or modified, and legal aid are not the only alternatives to the present system. The April 1994 edition of the Alberta Bar Association Journal provides a view of a delivery of legal services program that might be considered by the Canadian lawyer. ${ }^{16} \mathrm{~A}$ small but growing number of firms in the United States are providing services under prepaid legal service plans. Such plans, which operate somewhat like the more familiar health and dental plans, are offered by labour unions, fraternal organizations and credit card companies. These groups offer them as another advantage of membership. Businesses, as well, are including them in employee assistance programs. While the precise terms of the different plans vary, they generally cover most personal legal matters, and the law firms providing the services are either paid a monthly fee for every covered individual, or are paid per call made by a client. Other plans have a set reimbursement schedule for covered matters such as wills, real estate transactions and simple divorces. These plans today cover approximately 18.5 million people in the United States, and involve about 20,000 lawyers.

This concept will not necessarily be greeted favourably by all members of the profession. There will be debates on whether it allows for choice. An important concern is whether it may destroy the solicitor-client relationship. In addition, many of the arguments that presently surround the question of introducing medicare in the United States will be raised. The answer may be as simple as whether it is better than doing nothing.

It is most instructive that the American Bar Association Journal makes the point that the people who are using the plans are, for the most part, new to the legal system. These are people who would not use it were it not for the existence of these plans. There was a start in this direction in Canada by the auto workers union in the 1970s, but in understated Canadian fashion, little has been heard of its success or failure.

The value of the extension of legal services brings benefits not only for the client. It is the profession's responsibility, but it also brings rewards to the profession. It is a renewal of the profession's commitment to its public interest duty, which will increase the public's confidence in lawyers. Whether or not it is fair, lawyers are seen by many as concerned predominantly with their own pocketbooks and only incidentally with promoting the cause of justice. These various suggestions, if successfully implemented, will increase the public's access to legal services and demonstrate the dedication of lawyers to the rule of law. The importance of lawyers to the public good depends on public confidence.

While it is the professional duty of all lawyers to provide such service, their motives need not be entirely altruistic. Such work provides experience, and on occasion 
recognition. It is not uncommon for important cases to arise on a pro bono file. The well known Miranda and Gideon civil rights cases in the United States were pro bono.

William T. Coleman, a partner in the Washington D.C. office of O'Melveny \& Myers, a Los Angeles firm of approximately 700 lawyers, tells the story of the time the Chief Justice of the United States Supreme Court phoned him to ask him to take on a pro bono case. Chief Justice Warren Burger, knowing Coleman's reputation as a lawyer and that his firm was large enough to allocate the necessary resources, wanted Coleman to represent the United States government in challenging the tax exempt status of a private school which discriminated on the basis of race. Strangely, there was no means by which the government could finance it from the public purse. Coleman agreed, and went on to win a landmark case in the area of tax subsidies for private religious schools..$^{17}$

The absence of access to legal services, for whatever reason, creates a vacuum in the marketplace and, like nature, the marketplace abhors a vacuum. If the legal profession does not move to fill it, we can be certain that someone or something else will. When this happens, a large potential market will be lost, but more significantly, the profession will undergo changes. If the profession does not act to solve these problems specifically the cost of legal services - solutions to the detriment of the profession will be imposed.

Is it so difficult to see governments moving family law to some family service department of the government? Most provinces have moved to no-fault insurance. It is easy to conceive of tort law disappearing into an administrative process.

The proposals I have discussed may be inadequate or unworkable. I attempted nothing more than to raise the problems. I am content to rely on the profession in which I happily spent most of my life to find a solution.

Beyond the delivery of legal services is the question of who delivers them. The value, the importance and the integrity of our profession can be improved by ensuring that it is a true reflection of the gender and racial make-up of society. Progress has been made in this regard. Today the composition of law school students across the country is almost equally divided between men and women. But a law class that is simply $\mathbf{5 0}$ percent men and 50 percent women falls short unless within that group are qualified representatives of all racial and ethnic groups of our society. We have no choice in this matter if we want to continue to increase public confidence in lawyers. It is necessary that clients have a choice. It is not unusual that a client, particularly in her first encounter with the legal system, would feel more at ease with a member of her special society. I note from the conference program that this is to be the topic for one of the workshops to be held tomorrow. It is vital to remember that, in ensuring that the make-up of lawyers reflects our society, it is of no benefit if there is any compromise made in professional standards to achieve that goal. Such compromises are not necessary and should not be made. 
Quite apart from their self-interest, which is important, I encourage lawyers to remind themselves that the privilege of practicing law carries with it a duty to act in the public interest. If they are committed to the principle of justice, as their oath proclaims, then they must be committed to justice for all. This is not a radical or new idea. It is rather a return to our roots, and to enviable membership in a unique profession. 